\title{
Peacekeeping as a Tool of Foreign Policy 1
}

\author{
Maline Meiske \& Andrea Ruggeri
}

\section{Summary}

Peacekeeping is one of the principal activities and foreign policy tools implemented by the international community to create and 'maintain international peace and security'. Peacekeeping operations (PKOs) have grown in size and scope in the past few decades and have included traditional peacekeeping, multidimensional peacekeeping, and peace enforcement. Now PKOs pursue far-reaching objectives ranging from humanitarian assistance and the repatriation of refugees, over the disarmament, demobilisation and reintegration of former combatants, to liberal democratic assistance policies. Offering some descriptive statistics, this chapter suggests that the proliferation and increased scope of PKOs imply greater significance of peacekeeping as a tool of foreign policy. As such, peacekeeping operations are not deployed solely according to matters of global peace and security, but the deployment of and contribution to PKOs is increasingly shaped by individual state's foreign and security policy considerations. An increasing literature studying the supply side of peacekeeping offers a broad range of arguments for why countries contribute to PKOs referring to realism, liberalism, alliance politics, or domestic politics. Foreign and security policy goals that states try to attain by participating in PKOs include status enhancement and influence in the international system, the reduction of the threat of conflict diffusion into its own territory and of a potential influx of refugees, or the stabilisation of political relations, international trade, and alliance politics. The existing literature leaves us, however, with some lingering questions and methodological challenges that require further attention. Of particular importance are questions related to the politics of tool choice and the effectiveness of peacekeeping as a tool of foreign policy. Methodological challenges exist regarding data availability and collection as well as the appropriate modelling of cooperation between different organisations conducting PKOs and the interdependence of countries' decisions regarding their choice of peacekeeping as a tool of foreign policy.

Keywords: Peacekeeping, Foreign Policy, Peace Operation Contributors, Peace Operation Types, Peacekeeping Motivations

\section{Introduction}

"Peacekeeping has proven to be one of the most effective tools available to the UN to assist host countries navigate the difficult path from conflict to peace." (United Nations, 2017a)

Peacekeeping is often considered as the international community's tool for advancing peace and security. In 1948, the first modern-day peacekeeping operation (PKO) was deployed by a nascent United Nations (UN) as an innovative effort to observe and monitor peace processes. Nearly 70 years later, peace operations, including peacekeeping, peacebuilding, and peace enforcement, are now central to the international community's peace and security endeavours, whose objectives range from humanitarian assistance and the repatriation of refugees, to disarmament, demobilisation and reintegration of former combatants, as well as liberal democratic assistance policies. However, PKOs are not only deployed to address crises of global peace and security; the decision to deploy and contribute to PKOs is shaped by individual state's foreign and security policy considerations. Does the specific conflict influence the potential PKO contributor state's security and defence concerns? Does the conflict affect the flow of refugees or international trade? Does contribution to the PKO advance the contributor state's international standing? Does it advance its regional role? As 
this chapter will argue, peacekeeping is a tool available to governments to pursue their foreign and security policies, and it has grown in significance and comprehensiveness over the past three decades.

The last three decades have seen a "changed and changing landscape" of international relations and security (see United Nations Secretary-General, 2015, p. 9). The features of this post-Cold War world - including a high prevalence of intrastate wars, the rise of new security actors, and the recognition of new security threats - have led countries to transform their foreign and security policy agendas to become broader, more encompassing, and to redefine their concepts of security. Elevated policy foci include terrorism and organised crime, the proliferation of weapons of mass destruction, refugees and immigration, climate change, regional conflicts, state failure, and even humanitarian catastrophes (see for example European Council 2003, 2008). Over this period, peacekeeping has evolved into a more comprehensive and frequently applied instrument of crisis management and tool of foreign policy. For the purpose of this chapter, a tool of foreign policy is defined as an identifiable method through which government action is structured to pursue a state's goals in the international arena. ${ }^{2}$ So how does peacekeeping fit into this definition? Can peacekeeping be a tool of foreign policy?

First, a foreign policy tool has common and defining features that make it identifiable and thereby distinguishable from other instruments. Peacekeeping operations, generally, refer to activities that consist of military, police, and/or civilian personnel deployed in a country torn by conflict. These personnel aim to provide security, early peacebuilding, and political support (United Nations, 2017b). PKOs, however, encompass a broad spectrum of configurations and can vary in how they provide peace support. As delineated in the 2015 High-level Independent Panel an Peace Operations (HIPPO) report, these configurations "range from special envoys and mediators; political missions, including peacebuilding missions; regional preventive diplomacy offices; observation missions, including both ceasefire and electoral missions; to small, technical-specialist missions such as electoral support missions; multidisciplinary operations both large and small drawing on civilian, military and police personnel to support peace process implementation, and that have included even transitional authorities with governance functions; as well as advance missions for planning" (United Nations Secretary-General, 2015, p. 20).

Second, governments need to provide tools of foreign policy. While peacekeeping is commonly associated with the United Nations, PKOs are not limited to actions taken by the United Nations. Regional organisations, security alliances, ad-hoc coalitions, or even single states also implement peacekeeping operations. None of the international, regional, or security organisations have a standing army that they can call upon for PKOs and many organisations do not have an independent peacekeeping budget. Therefore, national governments must decide whether they want to participate in peacekeeping operations and allocate their resources to this specific tool of foreign policy. This means that each government decides whether they want to a) give their consent to a PKO, b) make the necessary financial contributions, and c) deploy military, police, and/or civilian personnel.

Third, foreign policy tools also affect and structure government action, which means that the processes and interactions underlying and generated by these tools are not just temporary but institutionalised. Peacekeeping is traditionally guided by three principles that structure government action and set peacekeeping apart as a tool for promoting international peace and security: consent of the parties to the conflict to the PKO, impartiality of the mission and individual peacekeepers, and non-use of force except in cases of self-defence and defence of the mandate (United Nations, 2017c). While these three principles have been questioned and stretched in recent years, they still guide the basic rules of engagement.

Finally, tools of foreign policy are employed by states to attain their goals in the international arena. The U.S. Department of State (2003), for instance, lists "achieve peace 
and security", "advance sustainable development and global interests", "promote international understanding", and "strengthen diplomatic and program capabilities" as its strategic objectives. Peacekeeping is one tool to realise these or parts of these broad goals, particularly international peace and security. Further, peacekeeping is a useful instrument to tackle more specific security and foreign policy concerns, such as the threat of terrorism, refugee inflows, and conflict diffusion. ${ }^{3}$

The remainder of this chapter will, first, explore the quantitative and qualitative transformation of peacekeeping and its rising relevance as a tool of foreign policy and, second, present specific foreign policy motivations for peacekeeping contributions. Specifically, the next section 'Evolution of Peacekeeping as a Tool of Foreign Policy' provides empirical descriptive trends, highlighting the growing application of peacekeeping as a foreign policy tool over time and space. The section 'Foreign Policy Motivations for Peacekeeping Contributions' outlines the different motivations and goals states pursue when participating in PKOs, as presented in the theoretical models and empirical findings of existing academic research. The final section 'Conclusion and Open Questions' wraps up with questions and puzzles about peacekeeping as a tool of foreign policy requiring further research and more definitive answers.

\section{Evolution of Peacekeeping as a Tool of Foreign Policy}

At present, ${ }^{4}$ there are 30 active peacekeeping operations with more than 190,000 personnel in the field (see Figures 1 and 2 below). Over 120 countries contribute uniformed personnel to these operations. UN peacekeeping spending reached approximately $\$ 8$ billion in 2016/17 (United Nations, 2017d). While the UN is the primary supplier of PKOs, a range of organisations engage in peacekeeping activities, including the North Atlantic Treaty Organization (NATO), Organization for Security and Co-operation in Europe (OSCE), African Union (AU), European Union (EU), Commonwealth of Independent States (CIS), Economic Community of West African States (ECOWAS), and the Pacific Island Forum (PIF). However, the above-mentioned actors have not always been so engaged in the practice of peacekeeping, as the size, prevalence, and scope of peacekeeping have changed substantially in the past 25 years. The descriptive statistics presented in this section illustrate this proliferation of PKOs, the rise in resources supplied to these operations by individual countries, the increased scope, goals, and functions of PKOs, and specific contributor-related trends. As such, peacekeeping has increased in relevance as a tool of conflict management for the international community and as a tool of foreign policy for individual countries.

Figure 1 shows the number of UN and non-UN peacekeeping operations deployed over time. It is readily apparent that PKOs have been deployed much more widely since the end of the Cold War. Until around 1990, there were only on average about four UN peacekeeping missions and three non-UN operations deployed each year. The number of UN and non-UN missions combined only reached eleven in 1965. A great surge in UN operations began in 1988 and between 1988-1993 alone, the UN conducted more PKOs than in the previous forty years combined. Non-UN operations followed a similar pattern and the number of operations increased dramatically after 1992. The high point in the post-Cold War period were an impressive 39 missions in 1999 and again in 2008.

This surge in PKOs can be attributed to both a rise in demand and a rise in supply, linked to the related systemic change of the post-Cold War international system (see Bellamy, Williams, and Griffins, 2010, pp. 94-97; Diehl and Balas, pp. 54-57). On the demand side, the 1990s saw a surge in the number of intrastate conflicts and civil wars. This rise in ongoing conflicts required additional missions to monitor and implement ceasefires and peace accords. Furthermore, successful missions of the late 1980s and early 1990s increased confidence in the utility and effectiveness of peacekeeping operations as an instrument available to the international community and individual countries. Alongside this increased demand, PKOs 
were also more readily supplied in the post-Cold War period. Peacekeeping during the Cold War era was marked by superpower politics and reciprocal blockage in the United Nations Security Council. The superpowers used the blockage of peacekeeping as an instrument in their foreign policy toolbox. This came to an end in the late 1980s and gave way to more cooperation in the Security Council and beyond. Additionally, the new post-Cold War order, marked by an accelerated process of globalisation, entailed a shift of foreign policy goals towards the promotion of a post-Westphalian conception of stable peace and humanitarian engagement. On top of that, the peace dividend of the early 1990s freed up military resources from traditional defence spending, which could then be deployed in PKOs. This increase in supply and demand enabled the rise of peacekeeping as a more frequent and potent tool of foreign policy (Bellamy, Williams, and Griffins, 2010, pp. 94-97).

[insert Meiske, Ruggeri_Figure 1 here] Figure 1: Number of UN and non-UN PKOs, 1948$2016^{5}$

Rising numbers in peacekeeping missions engender rising demands in resources, including financial resources, logistics, and personnel. These resources need to be supplied by individual countries in order to ensure that peacekeeping missions can be launched. Institutional arrangements regarding the supply of these resources differ slightly. For financial contributions to UN missions, UN members are assigned a fixed share of the financial costs of a UN PKO, based on a special scale of assessments under an intricate formula taking into account, among other things, the relative economic wealth of a member state and whether it is one of the five permanent members of the Security Council (United Nations, 2017e). Most non-UN missions, on the other hand, are financed on a voluntary basis. The basic rule for those peacekeeping missions is that "costs lie where they fall" - contributing countries send their personnel and equipment, and cover the associated costs (Tardy, 2013). Personnel contributions, which include military, police, and civilian personnel, are voluntary for both $\mathrm{UN}$ and non-UN missions. For UN missions, though, contributing countries are compensated at a rate of over $\$ 1,332$ per peacekeeper per month (United Nations, 2017e). Hence, UN compensation can imply that some countries with low costs for their troops can even earn money by sending them to UN missions.

Figure 2 presents the yearly number of UN and non-UN peacekeepers. Up until 1956, few peacekeepers - merely military observers - were deployed. This changed with the Suez Crisis and the launch of the First United Nations Emergency Force in November 1956, as well as the Organization of American States' (OAS) Inter-American Peace Force in the Dominican Republic. Thereafter, the average number of deployed peacekeepers settled at approximately 22,000 per year until the end of the Cold War. Corresponding to the rise in peacekeeping missions, the amount of deployed peacekeeping personnel rose sharply in the 1990s with a high point of almost $70,000 \mathrm{UN}$ personnel in 1993/4 and 150,000 non-UN personnel in $1995 / 6 .{ }^{6}$ The past 15 years saw another surge in deployed peacekeeping forces. UN deployments reached an all-time high of 106,830 peacekeepers in 2015 and non-UN peacekeeping reached a maximum of more than 250,000 in 2004. The non-UN numbers are predominantly driven by NATO's International Security Assistance Force (ISAF) in Afghanistan (Dec 2001-2014) with a size of around 130,000.

Apart from the personnel burden, peacekeeping operations also involve enormous financial burdens to cover personnel costs (military, police, and civilian personnel), equipment, logistics, infrastructure, communication, and medical expenses. UN peacekeeping spending rose tenfold from an annual average of $\$ 208.5$ million in the 1980 s to $\$ 3.5$ billion in the 1990s, and increased again to $\$ 8$ billion in 2016/17 (Khanna, Sandler, and Shimizu, 1999, p. 345; United Nations, 2017e). Even non-UN peacekeeping missions cost $\$ 121.591$ billion for the period from 1994 to 2006 (Gaibulloev, Sandler, and Shimizu, 2009, p. 828). ${ }^{7}$ Given that 
all personnel contributions and non-UN financial contributions to PKOs are voluntary, these figures suggest that countries have identified peacekeeping's increased relevance and value for their own policy goals.

\section{[insert Meiske, Ruggeri_Figure 2 here] Figure 2: Number of troops sent, 1948-2016 ${ }^{8}$}

Transformation of peacekeeping in the past 30 years was not only quantitative, but also qualitative in form (United Nations Secretary-General, 1995, p. 3). Peacekeeping as a tool to manage armed conflict has continuously evolved and adapted to respond to new crises in the most effective and appropriate way possible. As a result, PKOs have become more complex, encompassing a broad spectrum of configurations and functions. They have evolved into an instrument that countries can and do apply to an ever-greater scope of foreign policy goals.

The evolution of peacekeeping is often described in terms of generations, representing different types of PKOs. Scholars have differed in the number of categories they have ascribed to peacekeeping. Goulding (1993), for instance, found five types: preventive deployment, traditional peacekeeping, operations to implement a comprehensive settlement, operations to protect the delivery of humanitarian relief supplies, and deployment of a UN force in a country where the institutions of state have largely collapsed; Bellamy, Williams, and Griffin (2010) offer seven types; and Diehl, Druckman, and Wall (1998) even twelve. All of these types highlight different functions and goals of peacekeeping. To summarize this concisely, Figure 3 classifies all UN PKOs up to now into three peacekeeping types. For each year from 1948-2016, the proportion of traditional peacekeeping, multidimensional peacekeeping, and peace enforcement is depicted. While these types are not chronological, we can see a proliferation of more complex missions since the end of the Cold War.

Traditional peacekeeping is narrow in scope and range of activities. The focus lies on the monitoring of borders and establishment of buffer zones following ceasefire agreements with the goal to create an environment facilitating efforts of peaceful conflict resolution. The First United National Emergency Force (UNEF I), established in November 1956 and active until June 1967, was a traditional peacekeeping operation and the first of its kind. The mission was established to secure and supervise the end of the Suez Crisis, including the withdrawal of the armed forces of the United Kingdom, Israel, and France from Egypt, as well as the establishment of a buffer between Egyptian and Israeli forces. In establishing UNEF I, UN Secretary-General Dag Hammarskjold and UN General Assembly President Lester Pearson defined the three core principles of peacekeeping: (1) consent of the conflicting parties, (2) impartiality, and (3) minimum use of force (for self-defence). These principles have long been the standard of legitimacy guiding (UN) peacekeeping; they underlie traditional PKOs today and continue to guide other types of peacekeeping. However, more recent peacekeeping experiences, particularly from some PKOs in the 1990s, have shown that these principles sometimes conflict with peacekeeping demands as well as operational effectiveness. The international community has learned that, under certain conditions, actions compromising consent are necessary; it may be necessary to take sides against a party that endangers the operation; and the use of force may be required to protect the mission's objectives or humanitarian victims (see Lipson, 2007). Multidimensional peacekeeping and particularly peace enforcement embody these realisations.

Multidimensional peacekeeping gained prominence amid the shifting international context of the late 1980s/ early 1990s. This period saw the rise in intrastate wars while, freed from its previous rivalry, the Security Council could authorise more complex missions with expanded mandates to meet the additional demands of these new wars. The missions in Cambodia (UNACMI, 1991-2; UNTAC, 1992-3), Bosnia (UNPROFOR, 1992-5), and Somalia (UNOSOM I, 1992-3) differed qualitatively from earlier operations, merging humanitarian aid and state-building programmes with traditional peacekeeping tasks. The objectives of 
multidimensional peacekeeping operations are to promote the implementation of comprehensive peace agreements and to assist in building a sustainable peace. With this wider range of objectives, PKOs became multifunctional, expanding to include security, humanitarian, and political goals. The tasks typically added to traditional mission mandates include humanitarian assistance; monitoring human rights; the disarmament, demobilisation and reintegration of former combatants (DDR); repatriation of refugees; liberal democratic assistance policies to facilitate, support and supervise elections, the rule of law, and legitimate and effective governance institution. The growing list of tasks was captured in the 1995 Supplement to an Agenda for Peace (United Nations Secretary-General, 1995, p. 6).

Peace enforcement refers to missions characterised by an increased license to use force and are typically authorised under Chapter VII of the UN Charter. This has profound effects on the three core principles of peacekeeping: enforcement missions do not necessarily require the consent of the conflict parties and, while they try to be impartial in dealing with the involved parties, it may be necessary to use force against one or more of them to safeguard the objectives of the mission and to impose peace. Peace enforcement missions usually feature a range of responsibilities consonant with multidimensional peacekeeping operations. Notable UN peace enforcement missions include the United Nations Protection Force in Bosnia and Herzegovina (UNPROFOR, 1992-1995), the United Nations Mission in Sierra Leone (UNAMSIL, 1998-1999), and the United Nations Transitional Administration in East Timor (UNTAET, 1999-2002). Many peace enforcement missions, though, are not carried out by the UN but by regional organisations or ad hoc coalitions, especially if they are so-called "humanitarian interventions" focusing predominantly on human rights. Emblematic for these peace enforcement missions were NATO's involvements in former Yugoslavia, particularly in Kosovo (KFOR, 1999-today). Another example is the Australian-led International Force for East Timor (INTERFET, 1999-2000). These missions are often temporally limited and aim to create a peaceful environment in which the UN can carry out civilian activities.

\section{[insert Meiske, Ruggeri_Figure 3 here] Figure 3: Different types of UN PKOs, 1948-20169}

The quantitative and qualitative changes of peacekeeping were accompanied by shifts in the countries contributing to PKOs. As mentioned above, in most instances, countries can decide whether and how much they want to contribute to PKOs. Peacekeeping is a tool for countries to advance some of their own security and foreign policy goals. Thus, shifts in patterns of peacekeeping engagement offer valuable insights into the motivations for peacekeeping contributions. As we will see, these motivations are often related to foreign policy goals such as status enhancement or proximity to a conflict region.

During the Cold War period, PKOs were dominated by Western middle powers, such as Australia, Canada, Norway, and Sweden. While the superpowers of this period disengaged from peacekeeping efforts to keep their tensions and interests out of the "impartial" PKOs, middle powers hoped that by participating, they would receive special recognition for their engagement and thereby enhance their standing in the international system (see Cooper, 1997; Maloney, 2001). This arrangement continued until the early 1990s, as can be seen in Table 1. Table 1 presents the largest personnel contributors, including military, police, and civilian personnel, to UN peacekeeping missions from 1990-2016. ${ }^{10} 1990$ and 1991 saw Canada, Finland, Norway, and Austria among the largest three contributors. The end of the Cold War also enabled the permanent members of the UN Security Council to send personnel to peacekeeping operations, as done by France, the United Kingdom, and the US in 1992-1995. France's high ranking in 1992/3 was driven by their contribution of up to 5,700 troops to the United Nations Protection Force (UNPROFOR) in Croatia; and the United States' position in 1995 was driven by their contribution of 2,226 troops to the United Nations Mission in Haiti (UNMIH). Since then, we have seen non-Western states become the main personnel 
contributors to UN peacekeeping missions. The list of prominent non-Western donors include Pakistan, Bangladesh, and India, but also Nigeria in the early 2000s, and lately Ethiopia. From 2000-2014 Pakistan, Bangladesh, and India have remained the top three contributors of UN personnel. Pakistan contributed around 4,000 troops to the United Nations Mission in Sierra Leone (UNAMSIL, 1999-2006), thereafter around 3,500 each to the United Nations Mission in Liberia (UNMIL, 2003-2016) and the United Nations Mission in the Democratic Republic of Congo (MONUC, 1999-2010), later known as the United Nations Organization Stabilization Mission in the Democratic Republic of Congo (MONUSCO, 2011-today). Similarly, Bangladesh focused its contribution on UNAMSIL, UNMIL, and the United Nations Operation in Côte d'Ivoire (UNOCI, 2004-today); and India on the United Nations Mission in Ethiopia and Eritrea (UNMEE, 2000-2008), MONUC/MONUSCO, and the United Nations Mission in Sudan (UNMIS, 2005-2011), whose equipment and personnel was then transferred to United Nations Mission in South Sudan (UNMISS, 2011-today). The rising peacekeeping contributions of these non-Western countries are often explained by referring to the positional or status gains expected from participation in such activities. Another line of argument suggests that particularly developing states such as Bangladesh contribute to UN peacekeeping in order to receive the financial compensation provided by the UN and may actually generate profit by providing peacekeepers (see Victor, 2010; Lebovic, 2010).

[insert Meiske, Ruggeri_Table 1 here] Table 1: Largest troop contributors to UN PKOs, $1990-2016^{11}$

These contributing countries do not participate evenly across all peacekeeping missions. In principle, and if peacekeeping were independent from contributor-specific interests or foreign policy goals, one would expect an even contribution of peacekeeping resources to all regions of the world. Contributors, however, appear to have greater interest in certain regions than others. Figure 4 shows Europe's share of personnel contributions to UN PKOs grouped by the regions receiving the peacekeeping mission. Here, two interesting observations can be made. First, in line with the above discussion of Table 1, Europe's total share in the peacekeeping process has been in decline over the past 26 years. While Europe provided more than $60 \%$ of all peacekeepers in 1990 and 1991, its share was only between 6-7\% in the 2010s. Second, Europe continuously over- and under-contributes to certain regions. For instance, Europe's share of contributions to PKOs on the African continent always lies below its worldwide average, providing between 40\% (1991) and 1\% (2010-12) of all peacekeepers in Africa. This stands in contrast to its high contributions to missions in the Middle East (between $65 \%$ in 1990 and 35\% in 2015-16) as well as missions in Europe (between 40\% in 2002-2004 and $93 \%$ in 2016). ${ }^{12}$ Most notable among European contributions to PKOs in the Middle East are those to the United Nations Interim Force in Lebanon (UNFIL), the United Nations Peacekeeping Force in Cyprus (UNFICYP), and the United Nations Disengagement Observation Force (UNDOF) in the Golan Heights. All of these missions are located in or around the Mediterranean Sea - the European neighbourhood. This suggests that European participation in PKOs is driven by the conflict's proximity to their own territory.

Similar observations of uneven distributions of peacekeepers can be seen in Asia's share of contributions to UN PKOs (Figure 5). In this case, Asia under-supplies missions in the Middle East, but usually over-supplies missions in Asia and Africa, as compared to its worldwide share. The years in which Asia's share of contributions to PKOs within its own region dips below its worldwide average tend to be years with a low number of missions and peacekeepers deployed in Asia. For instance, only around 60 observers and civilian personnel were deployed in Asia, specifically Afghanistan (UNAMA) and Pakistan (UNMOGIP), between 2012 and 2016; and only 44 observers in 1993, also in Pakistan (UNMOGIP). Asia's 
high level of engagement in PKOs located in Africa can be attributed to Pakistan, India, and Bangladesh - the three major contributors to UN PKOs discussed above.

[insert Meiske, Ruggeri_Figure 4 here] Figure 4: Europe's share of contributions to UN PKOs, 1990-2016 ${ }^{13}$

[insert Meiske, Ruggeri_Figure 5 here] Figure 5: Asia's share of contributions to UN PKOs, $1990-2016^{14}$

\section{Foreign Policy Motivations for Peacekeeping Contributions}

The previous section has shown that the usage, relevance, and scope of peacekeeping have increased greatly in the last three decades. The international community in general and individual countries specifically have instrumentalised peacekeeping as a tool that can address threats and conflicts in a changed and changing security landscape. In order to enhance our understanding of this tool, we now review the motivations for countries to engage in peacekeeping. As the discussion will show, these motivations are typically part of a country's foreign policy agenda.

An increasing literature studying the supply side of peacekeeping has developed in recent years. These contributions offer a broad range of arguments for why countries contribute to PKOs, referencing themes connected to realism, liberalism, alliance politics, or domestic politics. In this context, the prominent question is what type of goods or set of benefits states can obtain for participating in peacekeeping. Peacekeeping can resemble a public good, a private good, or a combination of both. A public good is a good or benefit that is non-rival among nations and non-excludable to non-contributors and, thus, available to everybody, regardless of whether they have shared the cost of providing it. A private good, on the other hand, is rival and excludable and is only available to those who have born the costs (see Samuelson, 1954; Olson, 1965). From the perspective of the public good model, peacekeeping efforts to increase international peace and security benefit all countries. The end of a conflict and increased stability do not only favour the contributors to the peacekeeping mission but also promote the security of non-contributing countries. Characterising peacekeeping as public good, however, has profound implications as it implies the provision of peacekeeping is inevitably affected by collective action problems. This is related to the property of non-excludability, as other countries cannot be prevented from consuming a good - increased stability - even if many of those countries fail to contribute. This not only leads to free riding but can result in chronic or persistent undersupply of peacekeeping missions. This line of argument and the focus on the public nature of peacekeeping is pursued by Sanders and colleagues (for example, Khanna, Sandler, and Shimizu, 1998; Khanna, Sandler, and Shimizu, 1999; Shimizu and Sandler, 2002; Gaibulloev, Sandler, and Shimizu, 2009; Gaibulloev, George, Sandler, and Shimizu, 2015). Yet, the public nature of peacekeeping's ultimate aim of international peace and security does not keep countries from prioritising this objective among their foreign policy goals. India-as seen in Table 1, nowadays one of the main contributors to UN peacekeeping - even lists the "[p]romotion of international peace and security" among its core principles of state policy according to its 1949 Constitution. Article 51 reads that "[t]he State shall endeavour to - (a) promote international peace and security; (b) maintain just and honourable relations between nations; (c) foster respect for international law and treaty obligations in the dealings of organised peoples with one another; and (d) encourage settlement of international disputes by arbitration."

Many other scholars engaging in this field of study demonstrate that peacekeeping activities not only yield public but in addition also private benefits. The private good model highlights rivalrous and excludable country-specific benefits that motivate countries to 
contribute to PKOs and use them to achieve their foreign and security policy goals. Realist accounts focus on national self-interest to explain contributions to peacekeeping. As Findlay (1996, p. 8) put it: states participate in PKOs because it is "decidedly in their national security interests." One of these national security and foreign policy goals is greater or wider influence in shaping the international system. So-called middle powers are said to have an interest in the continuation of the international status quo and choose to dominate UN peacekeeping, which they consider an established tool of the international community (Neack, 1995). Examples include Canada, Sweden, or Australia during the Cold War period, and India or Pakistan who have dominated UN peacekeeping more recently. Another widespread perception is that peacekeeping is a positional or status good. Participation in peacekeeping enhances a country's prestige and standing in the international community, which it can then use to foster some of its foreign policy goals. It is argued that India, for instance, tries to strengthen its international status and power base by contributing to peacekeeping, hoping to get closer to its goal of becoming a 'great' power and eventually obtaining a permanent seat in the UN Security Council (Krishnasamy 2001, 2003a). Another example is Pakistan, whose peacekeeping participation is associated with its goal to strengthen its international image, reduce its isolation, and become more attractive to the international community-including the international economic and development funding that comes with it (Krishnasamy 2001). Similarly, Bangladesh hopes to attract foreign aid and international support for its economy (Krishnasamy 2003b). Since a PKO is located in a certain region, private, contributor-specific benefits are often present for countries nearby or with special interest in it. Countries located nearest the conflict region face the highest threat of conflict diffusion and might experience a decrease of their own security and stability. The European Union, for instance, follows the foreign policy goal of fostering stability, security, and prosperity in its neighbourhood. The PKOs in the Balkans in the 1990s and early 2000s - first conducted via NATO, later through the European Union with EUFOR Concordia in the Republic of Macedonia and EUFOR Althea in Bosnia and Herzegovina-are examples for how European countries tried to stabilise their own neighbourhood and periphery. More recently, the EU has adopted their European Neighbourhood Policy as a foreign policy instrument to bring Europe and its neighbours closer together and increase stability in the region. Another factor related to conflict proximity is an influx in refugees, which is often linked with negative economic and social effects (see Uzonyi, 2015). U.S. President Bill Clinton, for instance, invoked the need to stop refugee flows when he explained his decision to engage in peacekeeping in Haiti in 1994: "[...] [W] hen brutality occurs close to our shores, it affects our national interests. [...] Thousands of Haitians have already fled toward the United States, risking their lives to escape the reign of terror. As long as Cedras rules, Haitians will continue to seek sanctuary in our Nation. [...] The American people have already expended almost \$200 million to support them [...] [a]nd the prospect of millions and millions more being spent every month for an indefinite period of time loom ahead unless we act." Further foreign policy goals mentioned in the literature in relation to peacekeeping operations include economic considerations, such as trade interests, the protection of foreign direct investment (FDI), and the elimination of disruptions (Gaibulloev, Sandler, and Shimizu, 2009); or alliance considerations, such as the alliance security dilemma with the related fears of abandonment and entrapment (Snyder 1984; Bennett, Lepgold, and Unger, 1994), or the finding that countries prefer to deploy troops alongside allies with similar foreign policy preferences (Ward and Dorussen, 2016). To provide an overview, Table 2 summarises these and other relevant foreign policy-related motives for contributions to PKOs.

[Insert Meiske, Ruggeri_Table 2 here] Table 2: Foreign policy-related motives for contributions to peacekeeping operations as presented in the scholarly literature 


\section{Conclusion and Open Questions}

In this chapter we have argued that peacekeeping has been used as a tool available to governments to pursue their foreign and security policies. Peacekeeping has grown in significance and comprehensiveness over the past three decades. Offering some descriptive statistics, we suggested that the proliferation and increased scope of peacekeeping imply greater significance of PKOs as a tool of foreign policy. Moreover, changes in the composition of contributing countries could suggest that countries seem to follow their own foreign policy goals and that their polices can be shift over time. In the previous section, we have reviewed foreign policy motivations for peacekeeping contributions. The scholarly literature identified public and private goods as explanations for countries' contributions to PKOs, and particularly private goods are linked to specific foreign policy goals. The existing literature leaves us, however, with some lingering questions requiring further attention. We conclude this chapter by elaborating three substantive research areas in need of academic exploration and by highlighting three methodological challenges that researchers will need to tackle.

The first research area concerns the question of tool choice: Why do countries opt for peacekeeping as a foreign policy tool instead of alternative options? As Peters (2002, p. 552) argues, the selection of policy tools is inherently political: "political factors and political mobilization affect the initial selection of instruments and the ultimate implementation of policy." Relevant factors influencing tool choice are individual or collective interests, ideas or ideologies, individual actors, institutions, and the international environment (Peters, 2002, pp. 553-559). These factors and the mechanisms through which policy tools, including peacekeeping, are selected differ from country to country, which complicates comprehensive research. However, it is crucial to get a better understanding of these processes in order to coordinate peacekeeping contributions between countries. Conflict literature on the role of leadership versus institutional limitations (for example, Chiozza and Goemans, 2011; Horowitz, Stam, and Ellis, 2015), or the role of domestic audience costs (for example, De Meqsuita, Smith, Siverson, and Morrow, 2005; Weeks, 2014) can provide important insights for this avenue of research.

Second, related to the politics of tool choice is the topic of instrument evaluation. Instrument evaluation usually includes the examination of effectiveness and efficiency, inter alia. Effectiveness measures the degree of success in achieving intended objectives, while efficiency assess the results in relation to the costs. Is peacekeeping an effective and efficient tool? In order to answer this question, we need to be aware that peacekeeping has a twofold effect: it impacts the conflict dynamics within the receiving country or region and, at the same time, the foreign policy considerations of the contributing country. Some existing studies deal with the former effect and assess whether peacekeeping is effective according to its own goals, for instance whether peacekeeping actually creates lasting peace (see Fortna, 2004), or whether it successfully stops belligerent parties and protects civilians (see Di Salvatore and Ruggeri, 2017). The effectiveness of peacekeeping according to the achievement of a country's foreign policy goals, however, is understudied. Has a country gained more status or legitimacy through the deployment of peacekeepers? Were the national interests protected thanks to the engagement in a peace operation?

Third, even if we explore the questions of why peacekeeping is chosen as a foreign policy tool and whether it is an effective one, we still need to understand whether and, if so, why peacekeeping as tool of foreign policy has changed over time. We have shown how the scope of peacekeeping has increased with the evolution from traditional PKOs over multidimensional operations to peace enforcement. Is this change due to learning processes regarding foreign policy tool selection and implementation (see Levy, 1994)? Where did the learning take place? At the international level within international or regional organisations? 
Or within the countries contributing to PKOs and their internal bureaucracies and national leaders?

However, scholars willing to pursue the above questions and, at large, the study of peacekeeping as tool of foreign policy, should be aware of at least three empirical challenges. The first is asymmetric data information about peacekeeping operations. Data about UN PKOs is considerably more comprehensive than data about non-UN PKOs. It covers several different peacekeeping statistics, including mission-level and contributor-level data, monthly figures, gender-disaggregated data, and fatalities (see Clayton et al., 2017). Non-UN missions, on the other hand, often lack all of this information, mostly only providing yearly statistics on the size of the mission. Hence, we need more orderly and collective coordination for systematic data collection on peacekeeping from non-UN organisations. This is crucial because non-UN peacekeeping has become more significant over time. With this development, countries can also choose between different possible organisational frameworks for their peacekeeping involvement, which adds another dimension to their foreign policy decision-making. Related to the increased and increasing involvement of non-UN organisations is the second challenge: how to empirically disentangle cooperation, collaboration and overlapping of UN and non-UN PKOs. It would be misleading to treat UN versus non-UN operations as mere alternatives. We have studied many cases where we have seen the sequencing or simultaneous presence of different organisations, for instance in Kosovo with NATO's Kosovo Force, the United Nations Interim Administration Mission in Kosovo, and the OSCE Mission in Kosovo. Similarly, the Central African Republic hosted the African Union's International Support Mission to the Central African Republic (MISCA), France's Operation Sangaris, a European Union Force (EUFOR RCA), and the United Nations Multidimensional Integrated Stabilization Mission in the Central African Republic (MINUSCA) between 2013 and today. The academic literature defined several different forms of cooperation between the UN and regional organisations, such as the sequential, parallel and integrated deployment of troops (see Brosig, 2010), but it is unclear how this affects the foreign policy decision-making and the effectiveness of peacekeeping as a tool of foreign policy. Finally, we tend to study foreign policy and its related tools either monadically - does adopting a certain policy affect a country? - or dyadically - does the foreign policy of country A versus B affect their relationship? However, it seems that the decision to deploy soldiers in a PKO and the level of a country's commitment can be interdependent to the decisions, and therefore the foreign policies, of other countries. Hence, future research on peacekeeping as tool of foreign policy will have to embrace advanced research methods such as network analysis (for example, Ward and Dorussen, 2016) or spatial econometric models (for example, Beck, Gleditsch, and Beardsley, 2006).

In conclusion, and to our knowledge, this is the first work to systemize the thinking of peacekeeping as a tool of foreign policy. We hope this chapter will inspire the research interests of other scholars to contribute to the study of a core tool of foreign policy for countries and the international community: peacekeeping.

\section{References}

Auerswald, D. P. (2004). Explaining Wars of Choice: An Integrated Decision Model of NATO Policy in Kosovo. International Studies Quarterly 48(3), 631-662.

Baltrusaitis, D. (2008). Friends Indeed? Coalition Burden Sharing and the War in Iraq. Ann Arbor: ProQuest.

Beardsley, K. (2011). Peacekeeping and the Contagion of Armed Conflict. The Journal of Politics 73(4), 1051-1064. doi: 10.1017/s0022381611000764

Beardsley, K., \& Gleditsch, K. S. (2015). Peacekeeping as Conflict Containment. International Studies Review 17(1), 67-89. 
Beck, N., Gleditsch, K. S. and Beardsley, K. (2006). Space is more than geography: Using spatial econometrics in the study of political economy. International Studies Quarterly 50(1), 27-44.

Bellamy, A. J., Williams, P. D., Griffin, S. (2010). Understanding Peacekeeping ( ${ }^{\text {nd }}$ ed.). Cambridge: Polity Press.

Bellamy, A. J., Williams, P. D. (2015). Trends in Peace Operations, 1947-2013. In J. Koops, N. MacQueen, T. Tardy, \& P. D. Williams, The Oxford Handbook of United Nations Peace Operations (pp. 13-41). Oxford: Oxford University Press. doi: 10.1093/oxfordhb/9780199686049.013.1

Bennett, A., Lepgold, J., \& Unger, D. (1994). Burden-Sharing in the Persian Gulf War. International Organization 48(1), 39-75.

Bennett, A., Lepgold, J., \& Unger, D. (1996). Friends in Need: Burden Sharing in the Persian Gulf War. Basingstoke: Macmillan.

Beswick, D. (2010). Peacekeeping, Regime Security, and 'African Solutions to African Problems': Exploring Motivations for Rwanda's Involvement in Darfur. Third World Quarterly 31(5), 739-754. doi: 10.1080/01436597.2010.503566

Bove, V., \& Elia, L. (2011). Supplying Peace: Participation in and Troop Contribution to Peacekeeping Missions. Journal of Peace Research 48(6), 699-714. doi: $10.1177 / 0022343311418265$

Brosig, M. (2010). The Multi-actor Game of Peacekeeping in Africa, International Peacekeeping 17(3), 327-342. doi: 10.1080/13533312.2010.500142

Brysk, A. (2009). Global Good Samaritans: Human Rights as Foreign Policy. Oxford: Oxford University Press.

Bullion, A. (1997). India and UN Peacekeeping Operations. International Peacekeeping 4(1), 98-114. doi: 10.1080/13533319708413653

Chiozza, G., \& Goemans, H. E. (2011). Leaders and international conflict. Cambridge University Press.

Clayton, G., Kathman, J., Beardsley, K., Gizelis, T. I., Olsson, L., Bove, V., Ruggeri, A., Zwetsloot, R., van der Lijn, J., Smit, T., \& Hultman, L. (2017). The known knowns and known unknowns of peacekeeping data. International Peacekeeping, 24(1), 1-62. doi: 10.1080/13533312.2016.1226768

Clinton, B. (1994, September 15). Address to the Nation on Haiti. Retrieved from http://www.presidency.ucsb.edu/ws/?pid=49093

Cooper, A. (1997). Niche Diplomacy: Middle Powers After the Cold War. New York: St. Martin's Press.

De Mesquita, B. B., Smith, A., Siverson, R. M., \& Morrow, J. D. (2005). The Logic of Political Survival. Cambridge, MA: MIT Press.

Di Salvatore, J., \& Ruggeri, A. (2017). Peacekeeping Effectiveness. In Oxford Encyclopedia of Empirical International Relations. Oxford: Oxford University Press.

Diehl, P. F., \& Balas, A. (2014). Peace Operations ( $2^{\text {nd }}$ ed.). Cambridge: Polity.

Diehl, P. F., Druckman, D., \& and Wall, J. (1998). International Peacekeeping and Conflict Resolution A Taxonomic Analysis with Implications. Journal of Conflict Resolution 42(1), 33-55.

European Council (2003, December 12). A Secure Europe in a Better World: European Security Strategy. Retrieved from https://www.consilium.europa.eu/uedocs/cmsUpload/78367.pdf

European Council (2008, December 11). Report on the Implementation of the European Security Strategy: Providing Security in a Changing World [S407/08]. Retrieved from http://www.consilium.europa.eu/uedocs/cms_data/docs/pressdata/en/reports/104630.pdf

Findlay, T. (1996). The new peacekeeping and the new peacekeepers. In T. Findlay, Challenges for the New Peacekeepers (pp. 1-31). Oxford: Oxford University Press. 
Fortna, V. P. (2004). Does peacekeeping keep peace? International intervention and the duration of peace after civil war. International Studies Quarterly 48(2), 269-292.

Gaibulloev, K., Sandler, T., \& Shimizu, H. (2009). Demands for UN and Non- UN Peacekeeping: Nonvoluntary versus Voluntary Contributions to a Public Good. Journal of Conflict Resolution 53(6), 827-852. doi: 10.1177/0022002709338509

Gaibulloev, K., George, J., Sandler, T., \& Shimizu, H. (2015). Personnel Contributions to UN and Non-UN Peacekeeping Missions: A Public Goods Approach. Journal of Peace Research 52(6), 727-742. doi: 10.1177/0022343315579245

Global Policy Forum (2017). Size of UN Peacekeeping Operations. Retrieved from https://www.globalpolicy.org/security-council/peacekeeping/peacekeeping-data.html

Goulding, M. (1993). The evolution of United Nations peacekeeping. International Affairs (Royal Institute of International Affairs 1944-) 69(3), 451-464. doi: 10.2307/2622309

Government of India Ministry of Law and Justice (2015, November 9). The Constitution of India. Retrieved from http://lawmin.nic.in/olwing/coi/coi-english/coi-4March2016.pdf

Hayes, G. (1997). Canada as a Middle Power: The Case of Peacekeeping. In A. Cooper, Niche Diplomacy: Middle Powers After the Cold War (pp. 73-89). New York: St. Martin's Press.

Horowitz, M. C., Stam, A. C., \& Ellis, C. M. (2015). Why Leaders Fight. Cambridge: Cambridge University Press.

International Peace Institute (2017, March). IPI Peacekeeping Database. Retrieved from www.providingforpeacekeeping.org

Kammler, H. Not for Security Only: The Demand for International Status and Defence Expenditure. Defence and Peace Economics 8(1), 1-16. doi: 10.1080/10430719708404866

Khanna, J., Sandler, T., \& Schimizu, H. (1998). Sharing the Financial Burden for U.N. and NATO Peacekeeping, 1976-1996. Journal of Conflict Resolution 42(2), 176-195.

Khanna, J., Sandler, T., \& Schimizu, H. (1999). The Demand for UN Peacekeeping, 19751996. Kyklos 52(3), 345-368.

Krishnasamy, K. (2001). Recognition for Third World Peacekeepers: India and Pakistan. International Peacekeeping 8(4), 56-76. doi: 10.1080/13533310108413920

Krishnasamy, K. (2003a). The Paradox of India's Peacekeeping. Contemporary Southeast Asia 12(2), 263-280. doi: 10.1080/095849302000147708

Krishnasamy, K. (2003b). Bangladesh and UN Peacekeeping: The Participation of a 'Small' State. Commonwealth and Comparative Studies 41(1), 24-47. doi: 10.1080/713999607

Lebovic, J. H. (2004). Uniting for Peace? Democracies and United Nations Peace Operations after the Cold War. Journal of Conflict Resolution 48(6), 910-936. doi: 10.1 $177 / 0022002704269357$

Lebovic, J. H. (2010). Passing the Burden: Contributions to UN Peace Operations in the Post-Cold War Era. Unpublished manuscript.

Levy, J. S. (1994). Learning and foreign policy: Sweeping a conceptual minefield. International Organization 48(2), 279-312.

Lipson, M. (2007). Peacekeeping: organized hypocrisy?. European Journal of International Relations 13(1), 5-34. doi: 10.1177/1354066107074283

Maloney, S. M. (2001). Canada and UN Peacekeeping. St-Catherines: Vanwell Publishing.

Neack, L. (1995). UN Peace-keeping: In the Interest of Community or Self?. Journal of Peace Research 32(2), 181-196.

Olson, O. (1965). The Logic of Collective Action: Public Goods and the Theory of Groups. Cambridge, MA: Harvard University Press.

Peters, G. B. (2002). The Politics of Tool Choice. In L. Salamon, The Tools of Government: A Guide to the New Governance (pp. 552-564). Oxford: Oxford University Press.

Pevehouse, J. C. (2002). Democracy from the Outside-In? International Organizations and Democratization. International Organization 56(3), 515-549. 
Salamon, L. M. (2002). The New Governance and the Tools of Public Action: An Introduction. In L. M. Salamon, The Tools of Government: A Guide to the New Governance (pp. 1-47). Oxford: Oxford University Press.

Samuelson, P. A. (1954). The Pure Theory of Public Expenditure. The Review of Economics and Statistics 36(4), 387-389.

Shimizu, H., \& Sandler, T. (2002). Peacekeeping and Burden-Sharing, 1994-2000. Journal of Peace Research 39(6), 651-668.

Snyder, G. H. (1984). The Security Dilemma in Alliance Politics. World Politics 36(4), 461495.

Thakur, R. (1980). Peacekeeping and Foreign Policy: Canada, India and the International Commission in Vietnam, 1954-1965. British Journal of International Studies 6(2), 125153.

Tardy, T. (2013). Funding Peace Operations: Better Value for EU Money. European Union Institute for Security Studies Brief 38. Retrieved from http://www.iss.europa.eu/uploads/media/Brief_38_Funding_peace_operations.pdf

United Nations (2017a). What is peacekeeping?. Retrieved from http://www.un.org/en/peacekeeping/operations/peacekeeping.shtml

United Nations (2017b). Peacekeeping operations. Retrieved from http://www.un.org/en/peacekeeping/operations/

United Nations (2017c). Principles of UN peacekeeping. Retrieved from http://www.un.org/en/peacekeeping/operations/principles.shtml

United Nations (2017d, March 31). Peacekeeping Factsheet. Retrieved from http://www.un.org/en/peacekeeping/resources/statistics/factsheet.shtml

United Nations (2017e). Financing peacekeeping. Retrieved from http://www.un.org/en/peacekeeping/operations/financing.shtml

United Nations (2017f). List of Peacekeeping Operations 1948-2013. Retrieved from http://www.un.org/en/peacekeeping/documents/operationslist.pdf

United Nations (2017g). Peacekeeping statistics. Retrieved from http://www.un.org/en/peacekeeping/resources/statistics/

United Nations Secretary-General (1995, January 25). Supplement to an Agenda for Peace: Position Paper of the Secretary-General on the Occasion of the Fiftieth Anniversary of the United Nations [A/50/60-S/1995/1]. Retrieved from http://repository.un.org/bitstream/handle/11176/42208/A_50_60\%3bS_1995_1EN.pdf?sequence $=21 \&$ isAllowed $=y$

United Nations Secretary-General (2015, June 17). Report of the High-Level Independent Panel on Peace Operations on uniting our strengths for peace: politics, partnership and people [A/70/95-S/2015/446]. Retrieved from http://www.un.org/en/ga/search/view_doc.asp?symbol=S/2015/446

U.S. Department of State (2003, December). Department of State Strategic Objectives and Strategic Goals. Retrieved from https://www.state.gov/s/d/rm/rls/perfrpt/2003hlts/html/28732.htm

Uzonyi, G. (2015). Refugee Flows and State Contributions to Post-Cold War UN Peacekeeping Missions. Journal of Peace Research 52(6): 743-757. doi: $10.1177 / 0022343315574353$

Velazquez, A. C. S. (2010). Why some states participate in UN peace missions while others do not: an analysis of civil-military relations and its effects on Latin America's contributions to peacekeeping operations. Security Studies 19(1), 160-195. doi: 10.1080/09636410903546822

Victor, J. (2010). African Peacekeeping in Africa: Warlord Politics, Defense Economics, and State Legitimacy. Journal of Peace Research 47(2), 217-229. doi:

$10.1177 / 0022343309354142$ 
Ward, H., \& Dorussen, H. (2016). Standing Alongside Your Friends: Network Centrality and Providing Troops to UN Peacekeeping Operations. Journal of Peace Research 53(3), 392408. doi: $10.1177 / 0022343316628814$

Weeks, J. L. P. (2014). Dictators at war and peace. Ithaca, NY: Cornell University Press.

Williams, P. D. (2016). Global and Regional Peacekeepers. Part of Discussion Paper Series on Global and Regional Governance, Council on Foreign Relations.

\footnotetext{
${ }^{1}$ We thank Adam McCauley for his suggestions and editing.

2 This definition and the following discussion are based on Lester Salamon's definition of tools of public action (2002, pp. 19-20).

${ }^{3}$ There are studies that have empirically shown how the deployments of PKOs tend to limit transitional diffusion of conflict (Beardsley, 2011; Beardsley and Gleditsch, 2015). However, we still miss systematic studies on the effects of PKOs on terrorism and refugees' flows.

${ }^{4}$ December 2016.

5 Source: UN PKOs: United Nations, 2017f; Non-UN PKOs: based on Bellamy and Williams, 2015; and Williams, 2016. (Non-UN PKOs include regional organisations, security alliances, ad hoc coalitions, and individual states.)

${ }^{6}$ The surge in UN peacekeepers was caused by the operations in Cambodia, the former Yugoslavia, and Somalia, while the rise in non-UN peacekeepers can be traced back to NATO's Implementation and Stabilisation forces in Bosnia and Herzegovina.

${ }^{7}$ These numbers include the Stabilisation Force in Bosnia and Herzegovina, the Kosovo Force in Kosovo, the International Security Assistance Force in Afghanistan, and the Multinational Force-Iraq.

${ }^{8}$ Source: UN PKOs: Global Policy Forum (2017); and United Nations (2017g); Non-UN PKOs: based on Bellamy and Williams, 2015; and Williams, 2016. (An important caveat here is that non-UN data is not as comprehensive as UN data: no within-mission variation is recorded and data for some early non-UN missions is missing.)

9 Source: Authors' own coding (based on mission statements).

${ }^{10}$ The focus on UN data is based on the limited availability of data for non-UN missions.

${ }^{11}$ Source: International Peace Institute (2017); calculations done by authors.

${ }^{12}$ As a side note, Europe hosted no PKOs in 1990-1991; a great deployment of troops (up to about 40,000) occurred with the United Nations Protection Force (UNPROFOR) in Croatia during the Yugoslav Wars from February 1992 to March 1995; and since 2009 only around 15 peacekeepers are deployed on in Europe. These non-military personnel are part of the United Nations Interim Administration Mission in Kosovo (UNMIK), which was established in 1999. Most of these few observers and civilian police personnel are from other European countries, as can be seen in Figure 4.

13 Source: International Peace Institute (2017); calculations done by authors.

14 Source: International Peace Institute (2017); calculations done by authors.
} 